\title{
Implications of Climate Change on Streamflow of a Snow- Fed River System of the Northwest Himalaya
}

\author{
Vaibhav SHARMA1*, Varunendra Dutta MISHRA ${ }^{1}$, Pawan Kumar JOSHI² \\ 1 Snow and Avalanche Study Establishment, Chandigarh 160o36, India \\ 2 TERI University, Institutional Area, Delhi 110o7o, India \\ *Corresponding author, e-mail: vaibhavsharma51@gmail.com
}

(C) Science Press and Institute of Mountain Hazards and Environment, CAS and Springer-Verlag Berlin Heidelberg 2013

\begin{abstract}
Air temperature and snow cover variability are sensitive indicators of climate change. This study was undertaken to forecast and quantify the potential streamflow response to climate change in the Jhelum River basin. The implications of air temperature trends $\left(+0.11^{\circ} \mathrm{C} /\right.$ decade $)$ reported for the entire north-west Himalaya for past century and the regional warming $\left(+0.7^{\circ} \mathrm{C} /\right.$ decade $)$ trends of three observatories analyzed between last two decades were used for future projection of snow cover depletion and stream flow. The streamflow was simulated and validated for the year 2007-2008 using snowmelt runoff model (SRM) based on in-situ temperature and precipitation with remotely sensed snow cover area. The simulation was repeated using higher values of temperature and modified snow cover depletion curves according to the assumed future climate. Early snow cover depletion was observed in the basin in response to warmer climate. The results show that with the increase in air temperature, streamflow pattern of Jhelum will be severely affected. Significant redistribution of streamflow was observed in both the scenarios. Higher discharge was observed during spring-summer months due to early snowmelt contribution with water deficit during monsoon months. Discharge increased by $5 \%-40 \%$ during the months of March to May in 2030 and 2050. The magnitude of impact of air temperature is higher in the scenario-2 based on regional warming. The inferences pertaining to change in future streamflow pattern can facilitate long term decisions and planning concerning hydro-power potential, water
\end{abstract}

Received: 24 January 2013

Accepted: 24 May 2013 resource management and flood hazard mapping in the region.

Keywords: Snowmelt; Snow cover depletion curve (SCDC); Climate change; Global warming; Stream flow; SRM; Jhelum

\section{Introduction}

Climate change poses a threat to global fresh water resources and aquatic eco-systems. A slight shift in climatic pattern due to rising air temperature and varying precipitation is expected to largely affect mountainous river systems (Huber et al. 2005). Hydrologists also recognize that water yields could be significantly reduced in a warmer climate, with negative impacts upon regional water supplies (Larson et al. 2011). Amongst the most environmentally fragile regions, Himalayas are expected to be most vulnerable to climate change. Significant rise in air temperature by $1.6^{\circ} \mathrm{C}$ in the last century has been observed in the north-west Himalayas (Bhutiyani et al. 2007). This warming trend is higher than global average quoted by IPCC fourth assessment report. The north-western Himalayas are the source of major perennial rivers such as Indus, Jhelum, Satluj, Raavi and Chenab. These rivers are important fresh water resources and are crucial for the ecological and economical sustainability of fertile northern plains of India. The discharge of these rivers is primarily controlled 
by snow-glacial melt during spring-summer months and by south-west monsoons during rainfall season. Impacts of climate change are already occurring in these river basins, in the form of rising air temperature, depleting snowfall precipitation coinciding with rapid reduction of glaciers (Ageta 2001; Hewitt 2005; Bhutiyani et al. 2007; Shekar et al. 2010). Consequently, the discharge of most of these rivers has considerably decreased (Bhutiyani et al. 2008).

Jhelum River is one of the main tributaries of the Indus and is a strategically important river of north-west Himalaya. It is a principal source of irrigation in the downstream plains having a substantial agricultural water deficit (Archer and Fowler 2008). Due to lack of hydro-meteorological data and typical climatology, climate change studies have not been reported on Jhelum river basin. Thus an uncertainty is associated with the responses of this river towards the futuristic climate scenarios. Rising air temperature over the period can modify the snow cover depletion rate in a basin. Conjointly both of these can alter the streamflow and hence water availability in downstream regions (Jain et al. 2009). It is therefore important to understand the magnitude of the possible responses of hydrological regimes to future temperature scenarios.

Hence in the present study, futuristic streamflow of Jhelum River in two different climate change scenario was simulated using snowmelt runoff model (SRM). The SRM model was validated for Jhelum basin for the year 20072008. In this study, realistic climate change scenarios was assumed based on real time air temperature trends $\left(+0.11^{\circ} \mathrm{C} /\right.$ decade $)$ reported for overall north-west Himalayas over last century (Bhutiyani et al. 2009) and regional temperature trends $\left(+0.7^{\circ} \mathrm{C} /\right.$ decade $)$ analyzed between last two decades. Variation in streamflow with temperature rise and changing snow cover depletion rate was studied and quantified for the year 2030 and 2050.

\section{Study Area}

The study area comprises of the Jhelum basin up to the Safapora site located in Jammu and Kashmir. The selected catchment of the Jhelum River lies between $33^{\circ} 22^{\prime} 30^{\prime \prime} \mathrm{N}$ to $34^{\circ} 30^{\prime} 0^{\prime \prime} \mathrm{N}$ latitude and $74^{\circ} 15^{\prime} \mathrm{o}^{\prime \prime} \mathrm{E}$ to $75^{\circ} 31^{\prime} 34^{\prime \prime} \mathrm{E}$ longitude (Figure 1). It spans a total area of $9,508 \mathrm{~km}^{2}$ out of which only $1.2 \%$ is glaciated

The discharge measurement site is located at Safapora prior to Wullar Lake in the Kashmir valley, which is maintained by CWC (Central Water Commission). The Jhelum basin comprises of five sub-basins (Gulmarg, Banihal, Pahalgam, Sind and Valley). The Banihal and Gulmarg are situated on the lee-ward side of the Pirpanjal range whereas Pahalgam and Sind lie on the windward side of the Greater Himalayan range of Himalayas. 48\% $\left(4,564 \mathrm{~km}^{2}\right)$ of the basin area is a low-lying valley region. Sind sub-basin has the highest glacial cover whereas Banihal sub-basin is the only nonglaciated sub-basin. The hypsometric analysis shows that the elevation in the basin ranges from $1,500 \mathrm{~m}$ to $5,700 \mathrm{~m}$.

\section{Data Used and Processing}

In the present study, clear sky MODIS (Moderate Resolution Imaging Spectrometer) sensor imageries and in-situ hydro-meteorological data were used for futuristic streamflow simulation of Jhelum River.

\subsection{Hydro-meteorological Data}

The metrological data used in the present work was recorded at four SASE (Snow and Avalanche Study Establishment) field observatories in snow bound region. The summary of these observatories are given in Table 1. The daily discharge data of Safapora (J\&K), India was recorded by CWC (Central Water Commission) for the period of October-September (2007-2008).

\subsection{Satellite data and its processing}

Imageries from MODIS sensor on board Terra satellite were used for the SCA (Snow Cover Area) estimation. MODIS sensor scans the 2,330 $\mathrm{km}$ wide swath and acquires data in 36 spectral bands ranging from visible to thermal, with 12 bit radiometric resolution. All the MODIS images were geo-referenced to the Everest datum in ERDAS/ Imagine 9.1 (Leica Geosystems GIS \& Mapping LLC) with sub-pixel accuracy using nearest 


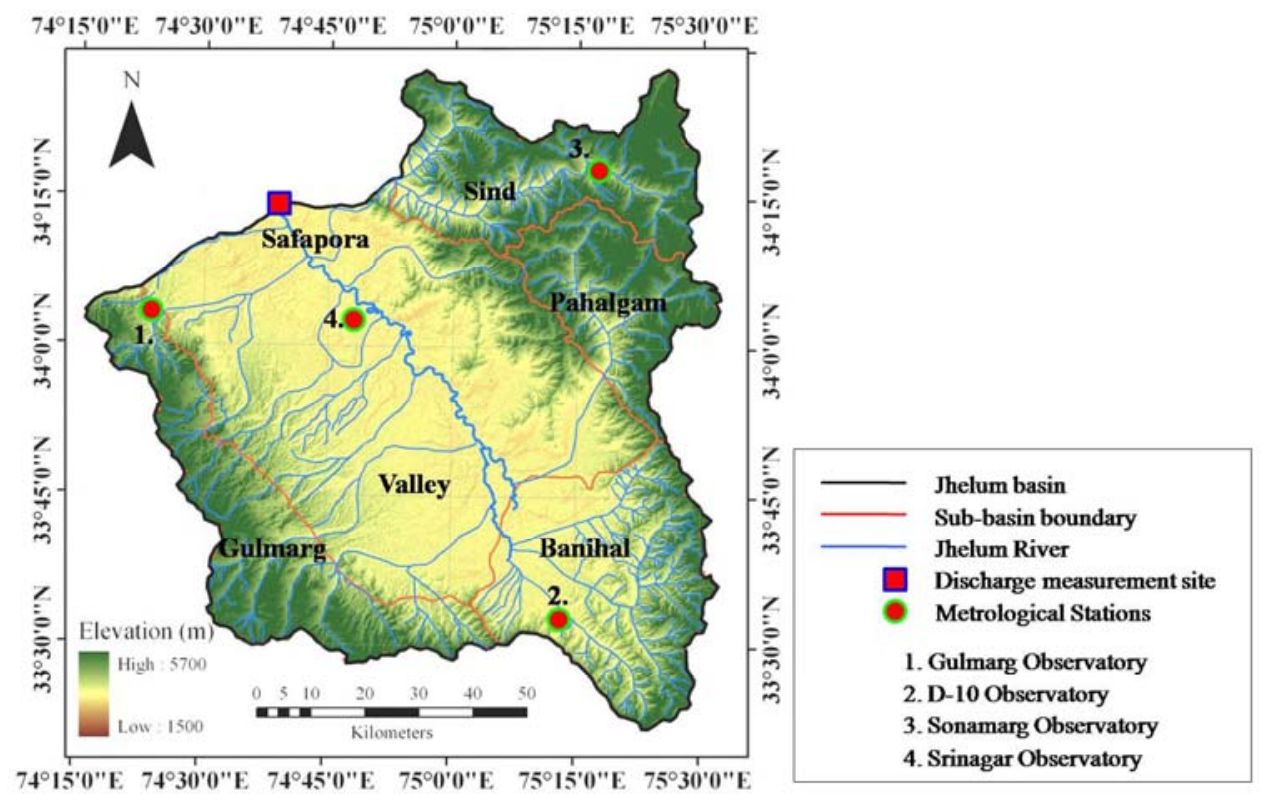

Figure 1 Jhelum River basin up to Safapora discharge measurement site with location of four metrological stations

Table 1 Summary of hydrological station and metrological observatories-represented region, mean altitude and data used (SASE: Snow and Avalanche Study Establishment; CWC: Central Water Commission)

\begin{tabular}{|l|l|l|l|l|l|}
\multicolumn{1}{|c}{ Items } & \multicolumn{1}{c}{ Safapora } & \multicolumn{1}{c}{ D-10 } & \multicolumn{1}{c|}{ Gulmarg } & \multicolumn{1}{c|}{ Sonamarg } & \multicolumn{1}{c|}{ Srinagar } \\
\hline Basin/Region & Entire basin & Banihal & Gulmarg & Pahalgam, Sind & Valley \\
\hline Data used & Streamflow & $\begin{array}{l}\text { Temperature, } \\
\text { Precipitation }\end{array}$ & $\begin{array}{l}\text { Temperature, } \\
\text { Precipitation }\end{array}$ & $\begin{array}{l}\text { Temperature, } \\
\text { Precipitation }\end{array}$ & Precipitation \\
\hline Organization & CWC & SASE & SASE & SASE & SASE \\
\hline
\end{tabular}

neighborhood re-sampling technique and subsequently remaining images were rectified by image to image registration.

Reflectance Image: Scaled integer (SI) values from satellite data were converted into the reflectance values using Equation (1) (Butt and Bilal 2011; Sharma et al. 2012):

$$
\mathrm{R}_{\mathrm{i} \lambda} \cdot \cos \theta=\mathrm{RS}(\mathrm{SI}-\mathrm{RO})
$$

where $R_{i \lambda}$ is the spectral reflectance of a pixel, $\theta$ is the solar zenith angle in degrees, scaled integer (SI) values are the DN (digital number) values which were scaled with in a defined dynamic range so that a single set of calibration parameters can be applied for every detector in a band, $R S$ is the reflectance scale value, $R O$ is the reflectance offset value. The values of reflectance scale and reflectance offset can be inferred from meta information available with the satellite data (Sharma et al. 2012).

\subsection{Topographic correction}

The topographic variability causes differential illumination due to steep and varying slopes angles in rugged Himalayan terrain. Therefore, topographic correction is essential for qualitative and quantitative analysis of SCA. Slope matching technique was applied on MODIS images (Nichol et al. 2006; Mishra et al. 2009). This technique compensates differential solar illumination due to undulating mountainous terrain. Here, differential illumination refers to the difference in radiance or reflectance from south aspect (sun-facing illuminated) and north aspect (shaded relief area). This method gives most acceptable results and retrieves the actual land cover information for low illumination areas $(\cos i \leq 0)$ in rugged mountain terrain. The topographically corrected reflectance is estimated using Equation (2):

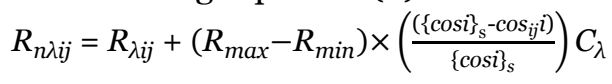


where $R_{n \lambda i j}$ is the normalized reflectance for image pixel $i j$ in wave band $\lambda ; R_{\lambda i j}$ is spectral reflectance on the tilted surface for image pixel $i j$ in wave band $\lambda, R_{\max }$ and $R_{\min }$ is maximum and minimum spectral reflectance and estimated from topographically uncorrected reflectance image, $\cos _{i j} i$ is illumination image for each pixel, $\{\cos i\}_{s}$ is illumination (IL) of the south aspect. $C_{\lambda}$ is normalization coefficient for different satellite bands and estimated using Equation (3):

$$
C_{\lambda}=\frac{S_{\lambda}^{\prime}-N_{\lambda}}{N_{\lambda}^{\prime}-N_{\lambda}}
$$

where $S_{\lambda}^{\prime}$ is the mean reflectance value on sunny slopes after first stage normalization, $N_{\lambda}$ is the mean reflectance value on shady slopes in uncorrected image, $N_{\lambda}^{\prime}$ is the mean reflectance value on shady slopes after first stage normalization.

Snow cover maps generation: Snow cover maps of the Jhelum basin were prepared using NDSI methodology (Hall et al. 2002; Riggs et al. 2002). In this technique, band ratioing was applied on the topographically corrected reflectance image. Snow cover pixels were separated from non-snow pixels using Equation (4):

$$
N D S I=\frac{\lambda \text { Green }-\lambda S W I R}{\lambda \text { Green }+\lambda S W I R}
$$

where $\lambda$ Green is the band- 4 of MODIS $(500 \mathrm{~m}$ pixel size); $\lambda S W I R$ is the band-6 of MODIS (500 m pixel size). A threshold value of 0.4 was used to discriminate the snow pixel using NDSI. In order to avoid merging of water bodies in the snow covered pixels criterion NDSI $>0.40$ and the reflectance of MODIS band-2 (Infrared band) >11\% was used (Hall et al. 2002; Sharma et al. 2012).

\section{Methodology}

\subsection{Streamflow simulation}

SRM is a widely used snow melt runoff model which can be applied on a basin of almost any size (Martinec et al. 2008). The SRM model used in the study is based on Equation (5):

$$
\left.Q_{n+1}=\left[C_{S} . \alpha_{n}\left(T_{n}+\Delta T_{n}\right) S_{n}+C_{R} P_{n}\right] \frac{A .10000}{86400}\left(1-k_{n+1}\right)+Q_{n} k_{n+1}\right]
$$

where $Q$ is the average daily discharge ( $\left.\mathrm{m}^{3} / \mathrm{sec}\right), \mathrm{A}$ is the area of the basin or zone $\left(\mathrm{km}^{2}\right), \mathrm{n}$ is the sequence of days, $T_{n}$ is the number of degree days ( ${ }^{\circ} \mathrm{C}$ day), $\Delta T_{n}$ is the temperature adjustment based on lapse rate ( ${ }^{\circ} \mathrm{C}$ day), $S_{n}$ is the ratio of SCA to total area, $P$ is the precipitation contributing to runoff $(\mathrm{cm}), C s$ is the runoff coefficient for snow, $C_{R}$ is the runoff coefficient for rain, $\alpha$ is the degree day factor $\left(\mathrm{cm} /{ }^{\circ} \mathrm{C} /\right.$ day) and $\mathrm{k}$ denotes recession coefficient indicating decline of discharge in a period without snowmelt or rainfall.

SRM requires determined values of runoff coefficients for effective runoff simulation. The value of runoff coefficients can vary on monthly basis depending on the hydro-meteorological conditions of the basin. The runoff coefficients take care of evapo-transpiration and other related runoff losses from the basin. Sharma et al. (2012), has reported the values of runoff and recession coefficients for the Jhelum basin based on the calibration and validation of four years (20052009) discharge data. In order to avoid overfitting of hydrograph, the values of calibration coefficients was taken from Sharma et al. (2012).

Snow cover area was derived from satellite images using remote sensing techniques. Temperature, precipitation data recorded at various ground observatories was used. Digital elevation model (DEM) of Advanced Spaceborne Thermal Emission and Reflection Radiometer (ASTER) with pixel size of $30 \mathrm{~m}$ was used to extract altitudinal zones (area elevation curve) of the basin. The basin was divided into seven elevation zones with altitudinal difference of $600 \mathrm{~m}$ for accurate streamflow simulation.

\subsection{Snow cover depletion curve (SCDC) of Jhelum basin}

Snow cover depletion curves (SCDC) is a required input in SRM model for accurate streamflow simulation. It represents the depleting SCA in different elevation zones during springsummer months. SCDC can be analyzed for each elevation zone using high temporal snow cover maps, DEM and daily mean temperature. The methodology of simulating SCDC has been immensely explained by Singh et al. (2003), Martinec et al. (2008), Jain et al. (2010), and Butt and Bilal (2011).

Snow cover depletion curves were simulated 
using the empirical exponential relationship between the SCA and cumulative daily mean temperature (Singh et al. 2003). SRM model takes SCDC values in the form of decimal portion of a zones snow covered area for each day. This relationship is explained in Equation (6):

$$
S C A=a \times \exp (-b \times C T M)
$$

where $C T M$ is the cumulative daily mean temperature $\left({ }^{\circ} \mathrm{C}\right)$ starting from first day of snowmelt till end of the snowmelt period; ' $a$ ' and ' $b$ ' are the calibration constants for the exponential equation. Melting in the Jhelum basin starts during early March month. Therefore March 1, 2008 was taken as reference date for calculation of cumulative mean temperature.

The estimated values of coefficient 'a', 'b' and $\mathrm{R}^{2}$ for different altitudes are given in Table 2. High correlation value $\left(R^{2}\right)$ indicates strong exponential relationship between CTM and SCA. SCA was calculated for all the elevation zones using binary snow cover maps and DEM. Basin daily mean temperature was extrapolated to the different elevation zone using global lapse rate of $-6.5^{\circ} \mathrm{C} / 1,000 \mathrm{~m}$. SCA of each elevation zone was plotted against corresponding cumulative mean temperature during the melting season and the value of calibration constant 'a' and 'b' was inferred. Once the depletion trend is established for all six elevation zones with good accuracy, a continuous SCDC was interpolated for the rest of the melting season.

Table 2 Values of coefficients a and b used in Equation (6) and $\mathrm{R}^{2}$ for different elevation zones.

\begin{tabular}{|l|l|l|l|}
\hline Elevation Zone $(\mathrm{m})$ & \multicolumn{1}{|c}{$a$} & $b$ & $R^{2}$ \\
\hline $1,500-2,100$ & 0.04513 & 0.58 & 0.976 \\
\hline $2,100-2,700$ & 0.01900 & 0.73 & 0.965 \\
\hline $2,700-3,300$ & 0.01910 & 0.97 & 0.950 \\
\hline $3,300-3,900$ & 0.00880 & 0.97 & 0.961 \\
\hline $3,900-4,500$ & 0.01632 & 0.99 & 0.985 \\
\hline $4,500-5,100$ & 0.00210 & 0.94 & 0.997 \\
\hline
\end{tabular}

The exponential relationship between CTM and SCA of each elevation zone shows high correlation with $\mathrm{R}^{2}>0.95$. It was found that SCA depletion take place only in an altitude range of 1,500-5,100 $\mathrm{m}$. The elevation zone 5,100-5,700 m represents negligible area of basin (0.0004\%) on ridges which permanently remain snow covered.
Hence the depletion curve of elevation zone-7 was not generated.

Using Equation 6, futuristic SCDC was predicted for each elevation zone based on the forecasted CTM in different climate change scenarios. The simulation was repeated using the higher values of temperature curves according to the assumed future climate. Under warmer climate it is expected that snow cover will recedes at faster rate leading to rapid SCA depletion from each elevation zone as compared to present scenario. Hence, in the present study, the impact of rise in temperature on SCA depletion in Jhelum basin was evaluated considering climate change scenarios. Projected SCDC for 2030 and 2050 were prepared for all six elevation zones based on the rise in temperature. The changes in SCA using SCDC are important input to SRM model for accurate daily discharge simulation and future forecast (Martinec et al. 2008).

\subsection{Definition of Climate change scenarios}

Air temperature has increased globally by $0.5^{\circ} \mathrm{C}$ to $1.1^{\circ} \mathrm{C}$ in the last 150 years (Jones et al. 1986a; 1986b; Vinnikov et al. 1990; Karl et al. 1995; Fallot et al. 1997; Zhai et al. 1999; Crowley 2000; IPCC 2001; Knappenberger et al. 2002; IPCC 2007; Bhuityani et al. 2009). This increase in temperature was not uniform and comprised of decadal cyclic variations. It has been reported that there was significant rise in temperature in the past fifty years with highest rate of increase during last two decades (Oerlemans 1994; Easterling et al. 1997; De and Mukopadhyay 1998; Qiang et al. 2004; Schaer et al. 2004; Cannone et al. 2008). Variable regional warming trends have been reported in the mountainous regions (Beniston 1997, 2003; Diaz and Bradely 1997; Wibig and Glowicki 2002; Diaz et al. 2003; Villaba et al. 2003; Vuille et al. 2003; Rebetez 2004; Day 2009; Wang et al. 2010).

Interestingly the warming trend in north-west Himalayas is higher than global average (Bhutiyani et al. 2007). However, the magnitudes of projected air temperature trends differ considerably within one Himalayan region to another. This variability is due to wide-spread altitude range and varying climatology affecting regional river systems (Pant 
and Borgaonkar 1984; Li and Tang 1986; Seko and Takahashi 1991; Bargaonkar et al. 1996; Pant et al. 1999; Sharma and Ganju 2000; Thompson et al. 2000).

Climate change and its impacts on river hydrology are generally studied using GCM's (general circulation model) or using assumed hypothetical climate change scenarios with hydrological models (Singh and Bengtsson 2004). GCMs are considered as most sophisticated method to generate future climate change scenarios on global scale (Lin et al. 2007). But GCMs also has certain limitations like inadequate temporal and spatial resolution required for hydrological modeling in Himalayas (Jain et al. 2010).

Given the limitation of GCMs, an alternate simple approach of defining futuristic impact of climate change scenarios was attempted. In these study, future climate scenarios was developed based on the realistic temperature trends across the Himalayas over the last century and regional temperature trends in the last two decades. The change in precipitation was not considered in the study, as the prime aim was to study the influence of rising air temperature on streamflow. Also it has been reported that precipitation has less effect on stream flow as compared to temperature rise (Arora et al. 2008; Jain et al. 2010). Further it is erroneous and difficult to project precipitation at river basin level in Himalayan region due to rugged topography and varying climatology.

Scenario-1 was assumed on the basis of analysis of temperature data of past century. The study has reported a rise of $0.11^{\circ} \mathrm{C} /$ decade for an entire northwest Himalayas (Bhutiyani et al. 2009). Scenario-2 was assumed on the basis of trend analysis of temperature data of scientific observatories located in the basin (Figure 2). The temperature data (19952011) of all three field observatories (D-10, Gulmarg, Sonamarg) was analyzed to study the regional temperature trends using linear regression. This data was analyzed to assume a scenario representing regional warming in Jhelum basin during last two decades. As it has been reported in many past studies that air temperature has risen considerably in the last two decades (IPCC, 2007; Oerlemans 1994; Easterling et al. 1997; De and Mukopadhyay

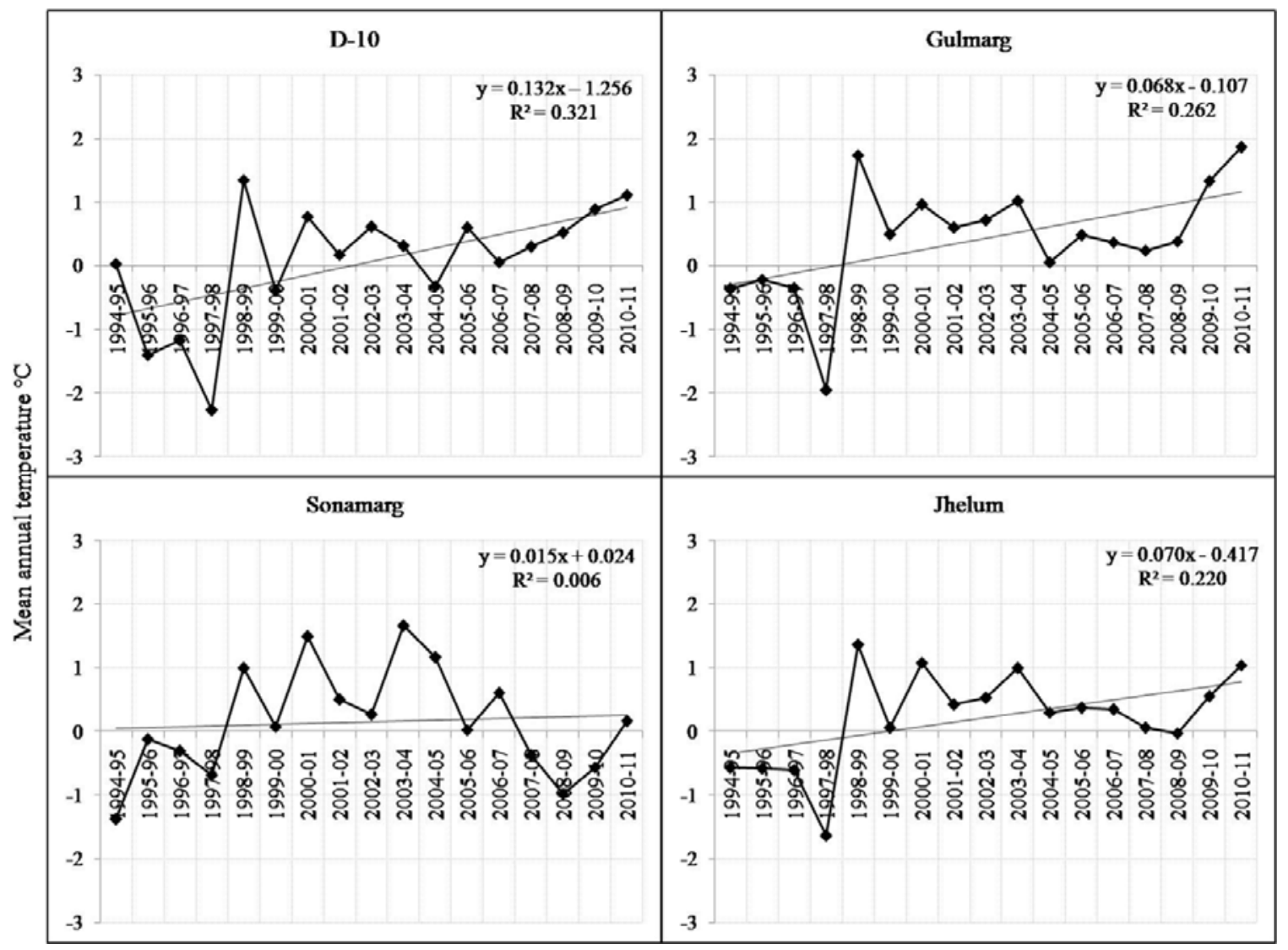

Figure 2 Time series analysis of mean temperature of different observatories in Jhelum River basin (1995-2011) 
1998; Qiang et al. 2004).

All three observatories show different temperature trends due to different geomorphology and climatology of each sub-basin (Table 3). The daily temperature of Jhelum basin (average of all three observatories) was taken as base line (BL) temperature. Changes in temperature according to both the scenarios were applied as absolute amounts to daily BL temperature data. Using the global lapse rate of $-6.5^{\circ} \mathrm{C} / 1,000 \mathrm{~m}$, mean temperature of all seven altitudinal zones of the basin was calculated.

Table 3 Regional temperature trends in Jhelum basin

\begin{tabular}{l|l} 
Observatory & Temperature trend $(1995-2011)\left({ }^{\circ} \mathrm{C} / \mathrm{yr}\right)$ \\
Gulmarg & $(+) 0.068^{*}$ \\
\hline D-10 & $(+) 0.132 *$ \\
\hline Sonamarg & $(+) 0.010$ \\
\hline Jhelum & $(+) 0.070^{*}$
\end{tabular}

Notes: (+) shows increasing trend, ${ }^{*}$ significant at $95 \%$ confidence interval using Mann-Kendall Test

\section{Results and Discussion}

\subsection{Stream flow simulation of Jhelum River}

The comparison between daily calculated and in-situ discharge for the year 2007-2008 is shown in (Figure 3).The simulated stream flow values were in the close proximity of in-situ Jhelum River discharge. High correlation coefficient value was observed between simulated and in-situ observed discharge (0.96, Nash-Sutcliffe coefficient) and

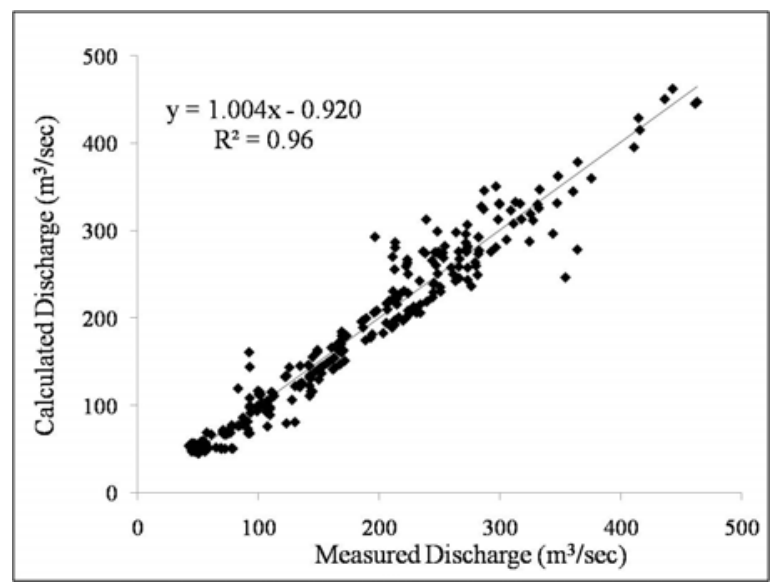

Figure 3 Comparison between computed and in-situ discharge of Jhelum River
(0.98, Pearson coefficient).

During early winter period (OctoberDecember) discharge reduced from $120-55 \mathrm{~m}^{3} / \mathrm{sec}$ due to reduction in air temperature and accumulation of snow cover. In peak winter period (January-February) estimated discharge value remains consistently low $\left(\sim 55 \mathrm{~m}^{3} / \mathrm{sec}\right)$. This accounts for the contribution of baseflow from the ground water reservoirs into the river. Baseflow is the major component of the streamflow during peak winter period when no rainfall and snowmelt occurs and keeps the river perennial (Jain et al. 2010; Sharma et al. 2012). This is the moisture amount which had infiltrated into the sub-surface zone before surface runoff generation during rain or from snow-glacial melt. Another source of baseflow is the glacial melt caused by geothermal heating from the earth surface. During springsummer period (March-June), higher discharge $\left(100 \mathrm{~m}^{3} / \mathrm{sec}-465 \mathrm{~m}^{3} / \mathrm{sec}\right)$ was estimated, which was due to rise in temperature. In monsoon period (July-September), estimated discharge remains $>175 \mathrm{~m}^{3} / \mathrm{sec}$.

Table 4 shows volume difference of the simulated and in-situ discharge in different months. It shows that during January-July the volume difference between simulated and in-situ discharge remains < 6\%. In August-September, maximum volume difference was observed. The validated SRM model was then used to study the effects of change in air temperature and modified snow cover depletion curves on streamflow of Jhelum River in future scenario.

Table 4 Average monthly volume difference (\%) in in-situ and simulated discharge during 2007-2008

\begin{tabular}{|l|l|l|l|l|l|}
\hline Oct & Nov & Dec & Jan & Feb & Mar \\
\hline o & o & -1 & 3 & 2 & 4 \\
\hline Apr & May & Jun & Jul & Aug & Sep \\
\hline-2 & -3 & -4 & -4 & 7 & 7 \\
\hline
\end{tabular}

\subsection{Effects of climate change on snow cover depletion curves}

SCDC of Jhelum basins for the year 2030 and 2050 for different climate scenarios are shown in Figures 4 and 5. It shows significant effect of rising temperature on snow cover depletion in the basin. Under warmer climate snow cover disappears rapidly resulting in early reduction of SCA. Intercomparison between the two climate change scenarios indicates rapid depletion of snow cover 


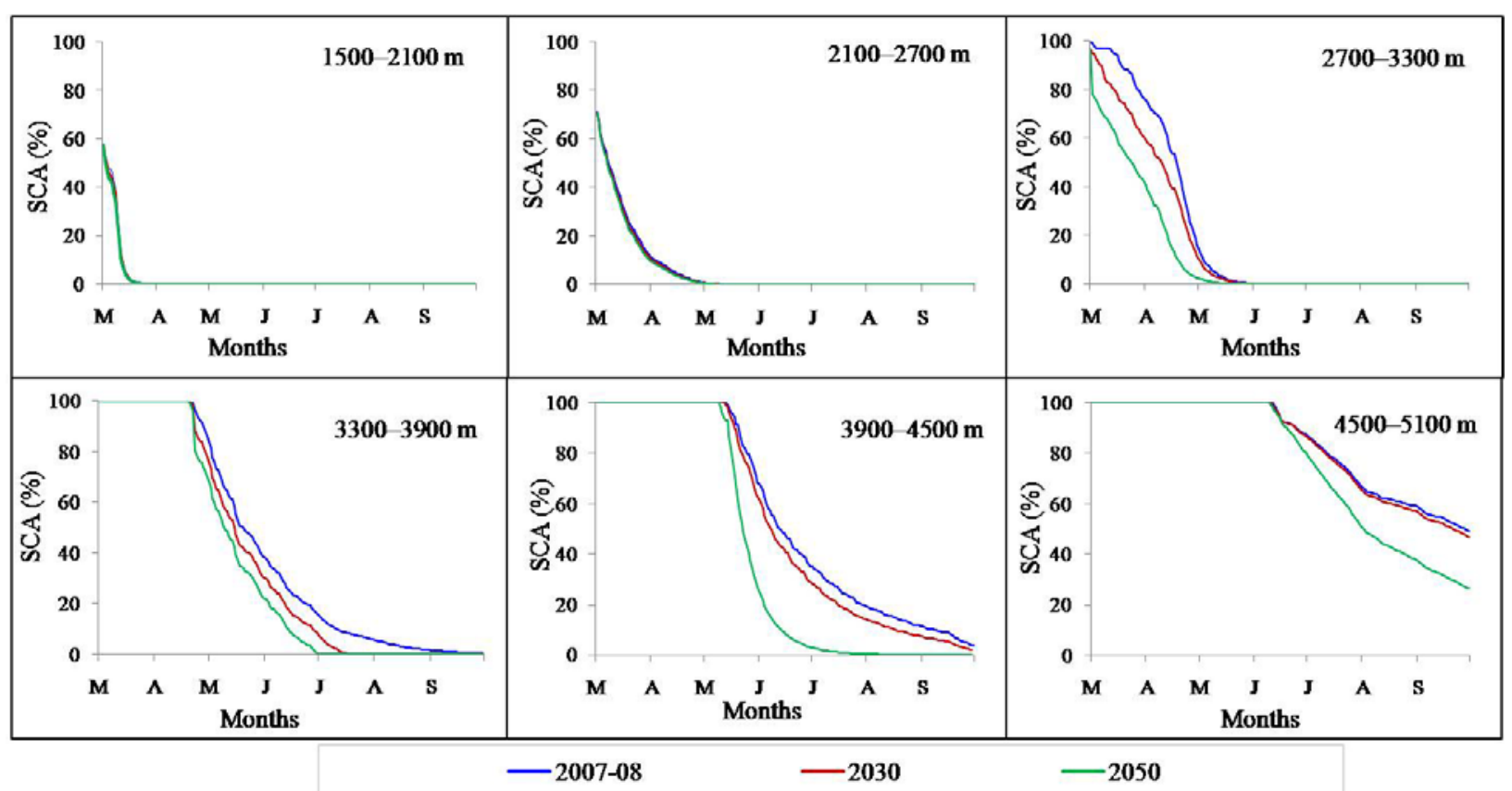

Figure 4 Snow cover depletion curves for different years-Scenario-1

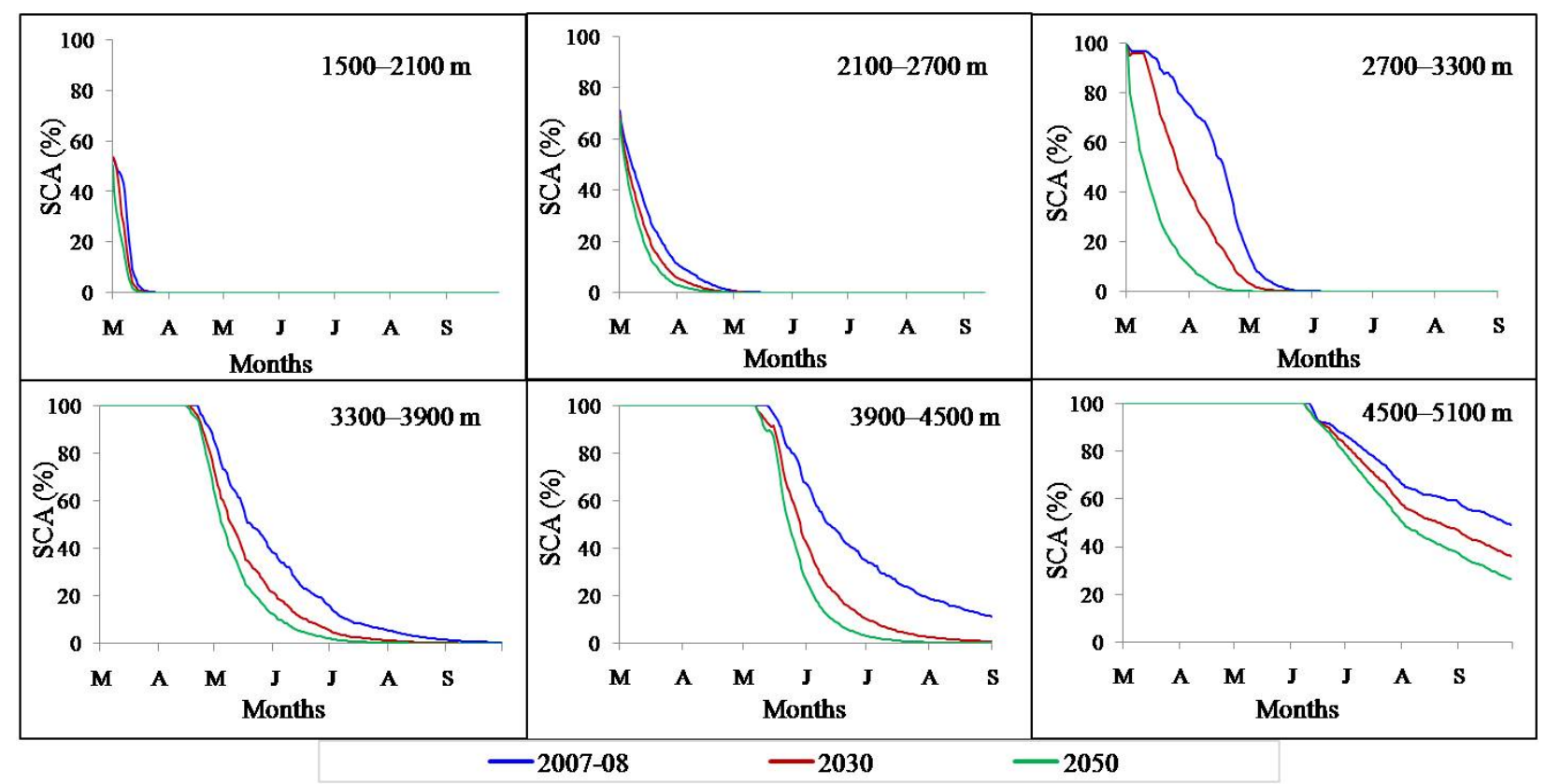

Figure 5 Snow cover depletion curves for different years- Scenario-2

in scenario-2 (Figure 5). Similar trend was observed for all the altitude zones $(1,500-5,100 \mathrm{~m})$. Table 5 shows the comparative account of seasonal average (March-September) SCA during 2030 and 2050 during different climate change scenario. In the elevation zone $1,500-2,100 \mathrm{~m}$ marginal decrease of $-0.2 \%$ in 2030 and $-0.8 \%$ in 2050 in seasonal mean SCA during scenario-1 was observed. In the same elevation zone, a higher depletion of $-0.5 \%$ in 2030 and $-0.12 \%$ in 2050 was observed (scenario-2).

The major reduction in mean seasonal SCA was observed in the altitude zone of 2,700-4,500 $\mathrm{m}$. In 2007-2008, the mean seasonal SCA in zone $2,700-3,300 \mathrm{~m}$ was $24 \%$ which is reduced to $19 \%$ and $11 \%$ in 2030 and 2050 respectively in scenario-1. In the same elevation zone mean seasonal SCA in scenario-2 was 14\% (2030) and 
Table 5 Average SCA (\%) (March-September) during 2030, 2050 under different climate change scenarios

\begin{tabular}{|c|c|c|c|c|c|}
\hline \multirow{2}{*}{$\begin{array}{l}\text { Elevation zone } \\
(\mathrm{m})\end{array}$} & \multirow{2}{*}{ 2007-2008 } & \multicolumn{2}{|c|}{2030} & \multicolumn{2}{|c|}{2050} \\
\hline & & Scenario-1 & Scenario-2 & Scenario-1 & Scenario-2 \\
\hline $1,500-2,100$ & 2.0 & 1.8 & 1.6 & 1.2 & 0.8 \\
\hline $2,100-2,700$ & 5.8 & 4.6 & 3.8 & 3.9 & 2.3 \\
\hline $2,700-3,300$ & 24 & 19 & 14 & 11 & 4 \\
\hline $3,300-3,900$ & 43 & 36 & 30 & 32 & 16 \\
\hline $3,900-4,500$ & 56 & 51 & 44 & 47 & 39 \\
\hline $4,500-5,100$ & 85 & 80 & 76 & 74 & 70 \\
\hline
\end{tabular}

$4 \%$ (2050). In the elevation zone 3300-3900 $\mathrm{m} \mathrm{a}$ higher depletion in mean seasonal SCA was observed (Table 5). These two zones comprised of $\sim 30 \%$ of total basin area. This early melting will produce higher snowmelt runoff in early springsummer period. Table 5 also shows that in the elevation $>4,500 \mathrm{~m}$ the affect of rise in air temperature on mean seasonal SCA is comparatively less than lower elevation zones. Figures 4 and 6 shows that increased air temperature will results in a shifting of snow cover depletion period, thus decreasing the persistence of snow cover in late summer and early monsoon period.

\subsection{Effect of climate change on streamflow of Jhelum Basin}

During winter months (October-February), high solid precipitation and low temperature lead to an almost constant discharge of the Jhelum. Hence impact of climate change on the streamflow of Jhelum was studied for March-September months. Impact of SCDC on streamflow of Jhelum River was also studied by simulating futuristic streamflow with and without modified SCDC. Further stream flow of Jhelum River during assumed climate change scenarios (Figure 2) with base line (BL) year (2007-2008) was compared.

\subsubsection{Simulation without SCDC}

In this simulation modified snow cover depletion curves were not considered for estimation of streamflow (Figure 6). As expected the simulation has shown misleading results. The results show that during both the climate change scenarios the discharge of the Jhelum will increase considerably in entire simulation period. An increment of 40-60\% was observed in streamflow in scenario-1 when SCDC was not used. Similarly in scenario-2 streamflow was estimated $80-90 \%$ more as compared to base line scenario in all the months.

The magnitude of change in streamflow in scenario-2 is greater than scenario-1. A slight redistribution of streamflow was also observed in both the scenarios. Figure 6 shows that the maximum discharge in BL year was observed during August month, whereas in both the future climate change scenarios the maximum discharge was observed in the month of May. In this simulation the snow cover was not gradually reduced with rising air temperature. Unrealistic availability of SCA till late summer has led to wrong results. There is a strong inter-relationship between air temperature and SCA present in the basin. Thus proportional reduction of snow cover area is very important to account for increased melt rates due to rising air temperature in climate change studies.

\subsubsection{Simulation with SCDC}

Figure 7 shows the comparison between stream flow of Jhelum River in BL year and assumed climate change scenario-1 and 2 for the year 2030 and 2050. Daily streamflow was simulated based on amplified temperature of assumed climate change scenarios and modified snow cover depletion curves.

Under warmer climate a significant redistribution of streamflow was observed along the peaks with a considerable early increment in the streamflow. In both the scenarios early snowmelt was observed in the month of March. This early rapid snowmelt occurrence and large discharge are attributed due to higher air temperature in the basin. It is also evident from the results that rapid snow melts during March-May months leads to lesser available discharge in later months. This increasing discharge gradually decreases with depletion of snow cover from higher attitudes, especially from elevation zone 2,100- 


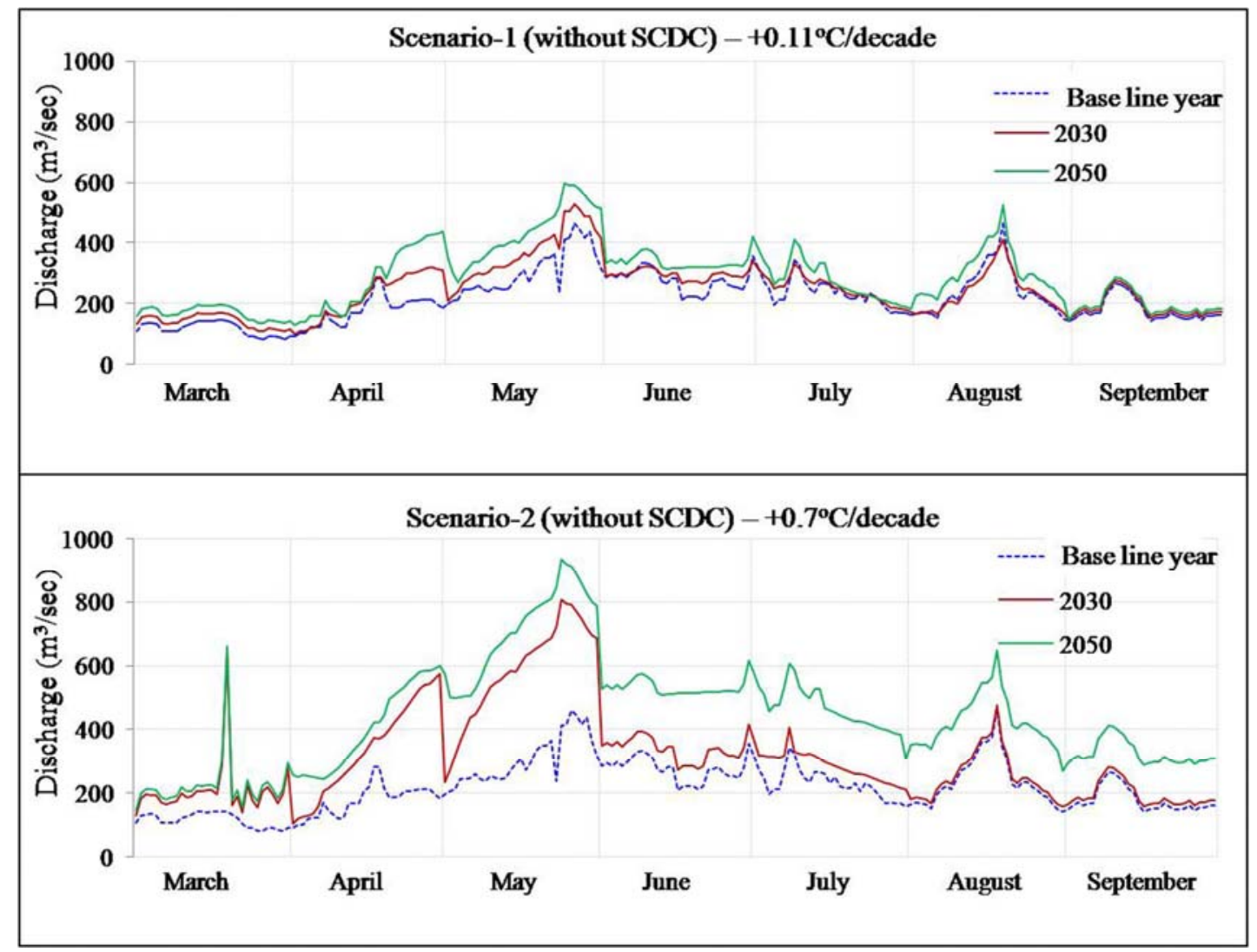

Figure 6 Daily streamflow for the changed climate change scenario without SCDC

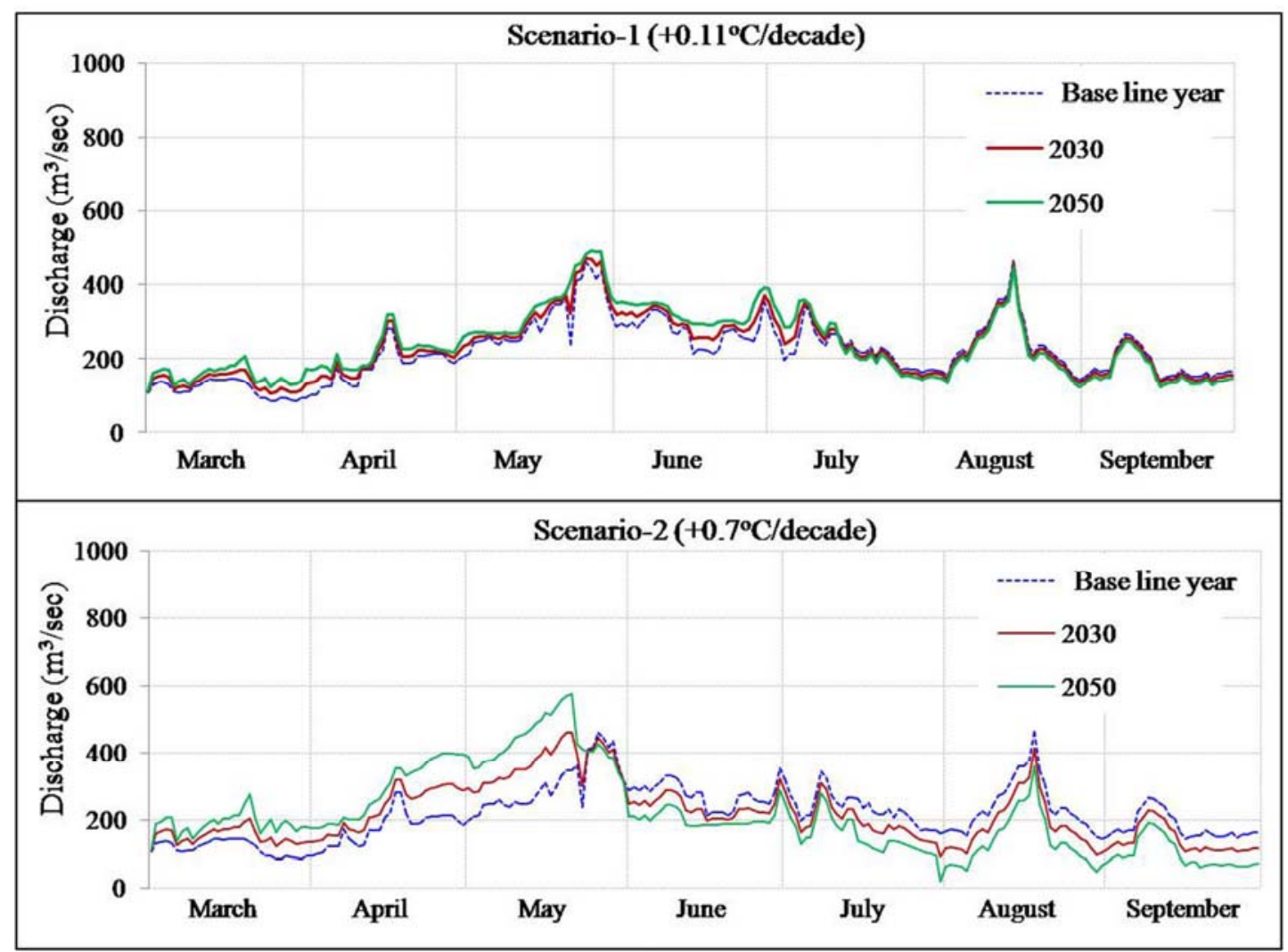

Figure 7 Daily streamflow for the changed climatic scenario with SCDC 
Table 6 Peak discharge values in different months on a particular day during two climate change scenarios

\begin{tabular}{|l|l|l|l|l|l|}
\hline \multirow{2}{*}{ Months } & $\begin{array}{c}\text { Base line year } \\
\left(\mathrm{m}^{3} / \mathrm{sec}\right)\end{array}$ & Scenario-1 & Scenario-2 & \multicolumn{2}{c|}{ Sc50 $\left(\mathrm{m}^{3} / \mathrm{sec}\right)$} \\
\hline March & 134 & 169 & 204 & 196 & Scenario-1 \\
\hline April & 282 & 301 & 318 & 320 & 354 \\
\hline May & 348 & 356 & 460 & 364 & 569 \\
\hline June & 354 & 372 & 320 & 390 & 287 \\
\hline July & 344 & 352 & 310 & 358 & 206 \\
\hline August & 463 & 453 & 411 & 445 & 360 \\
\hline September & 266 & 257 & 228 & 247 & 191 \\
\hline
\end{tabular}

4,500 $\mathrm{m}$ (Figures 4, 5 and 7). These elevation zones comprises of major snow covered area of the Jhelum basin. These elevation zones contribute majorly in snowmelt generation during springsummer months.

A transition period was observed in both the scenarios when the futuristic streamflow become lesser than the discharge of BL year (Figure 7). In scenario-1 this shift was observed in July month whereas this transition was observed in May month during scenario-2. The shift largely depends on the availability of snowmelt from the basin. In scenario2 , an early decrease in the stream flow was observed as the melt contributed from the snow cover decreases as compared to the base line year and scenario-1. It is also observed that during monsoon period (July-September) influence of rising air temperature is less prominent on discharge.

Table 6 shows the peak discharge values in different months during different temperature scenarios. It is observed that first peak discharge ( $134 \mathrm{~m}^{3} / \mathrm{sec}$ ) was observed on 17th April in BL year. Correspondingly higher simulation values are observed for scenarios-1 and 2 in the year 2030 and 2050. The magnitude of impact of air temperature is higher in scenrio-2. During the year 2030 in scenario-1, the peak value increased from $282 \mathrm{~m}^{3} / \mathrm{sec}$ to $301 \mathrm{~m}^{3} / \mathrm{sec}$. Similarly in scenario-2 the observed peak discharge on same date was $318 \mathrm{~m}^{3} / \mathrm{sec}$.

It further explains that, in scenario- 1 the peak discharge remains higher than base line year till July month. In August and September reduction in peak discharge values are observed than base line year. It is also evident from the results that scenario-2 has pronounced effect on discharge of Jhelum river. Higher values of peak discharge are observed till the month of May only. In corresponding months steep decline in the peak discharge values are observed in scenario-2.
Figure 8 shows the volume difference of discharge in different climate change scenarios with reference to the base line discharge volume. Here, volume difference is the percentage difference between the discharge in base line year and discharge in assumed climate change scenario. A negative volume difference refers to lesser volume discharge while positive values represent the higher discharge during a particular month as compared to BL year.

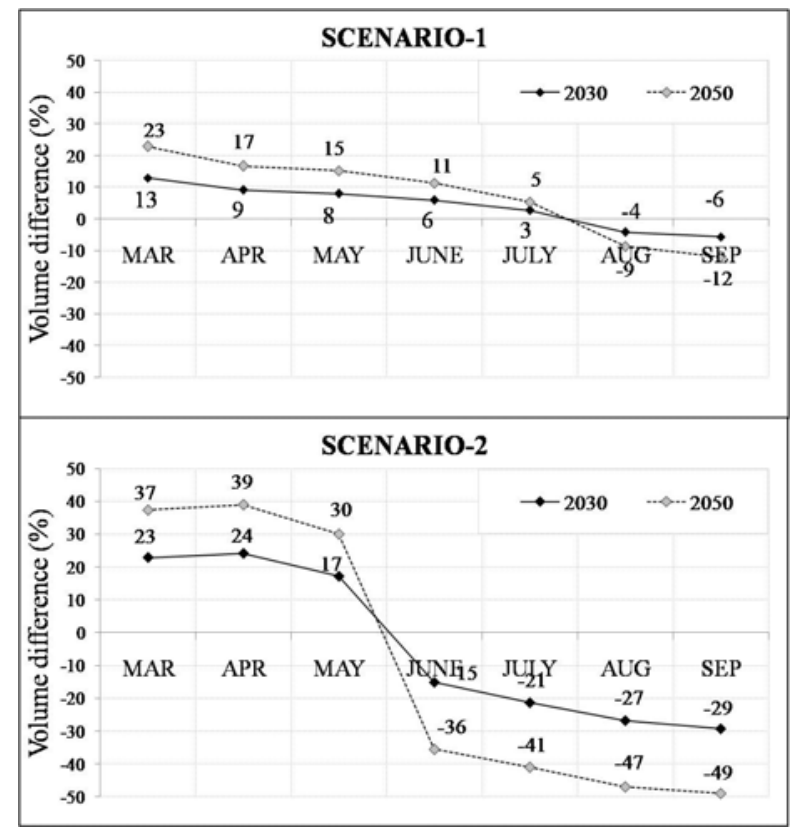

Figure 8 Volume difference in discharge in different climate change scenario in Jhelum River basin

A higher volume difference is observed in scenario-2 than scenario-1 during different months. The results show that maximum change in discharge volume is observed in March - April month. The scenario-1 simulation shows that there will be an increase of $>5 \%$ in discharge volume during March-June months in year 2030 and 2050. Further during July-September there 
will be lesser discharge as compared to base line year.

Scenario-2 simulation shows extreme increment of $>15 \%$ to $23 \%$ in discharge during March-May in the year 2030 while there could be a steep decline $(-15 \%$ to $-29 \%)$ in later months. Similarly during the year 2050, it is estimated that there will be $30 \%$ to $37 \%$ more discharge during March-May, whereas there will be corresponding discharge deficit $(-36 \%$ to $-49 \%)$ during JuneSeptember months.

\section{Conclusions}

In the north-west Himalayas, air temperature has increased gradually in the past century with enhanced warming trend in past two decades. Different regions of Himalaya shows variable warming trends with pronounced implications on the regional water resources.

In the present study, streamflow was simulated using SRM model assuming two climate change scenarios. Scenario-1 represents the warming trends based on reported temperature data analysis in past century in entire north-west Himalayas. Scenario-2 was assumed on the basis of air temperature trends during the last 15 years in different observatories located in Jhelum basin. Thus streamflow was simulated in two different real-time climate change environments. The two realistic scenarios was assumed keeping in mind the need to accommodate the warming trends based on long term data analysis and of past two decades.

The simulated results shows that in scenario2 the streamflow of the Jhelum River will be severely affected than in scenario-1. Considerable re-distribution of streamflow was observed in both assumed climate change scenarios. Increase in stream flow was observed during pre-monsoon months due to rapid snowmelt as a result of higher air temperature and decreased discharge in later months. The observed increased discharge may be beneficial with proper water resource management and planning. But the water deficit during late summer months will be crucial. This reduction in the discharge will affect water availability with strong implication on regional ecology and economy. Thus it can be concluded that increased higher temperature will result in redistribution of streamflow due to rapid snow melt in early snowmelt season. If snowmelt contribution shifts two months earlier and the monsoon season continues to begin in July month then Kashmir valley and downstream areas will be exposed to a longer water deficit summer. The study also shows the importance of SCDC in climate changesnowmelt related studies. Unrealistic exaggerated discharge values were observed from the simulation based on unmodified SCDC. Thus proportionate modifications in SCDC with rising air temperature are of utmost important during streamflow simulations.

\section{Acknowledgments}

The authors would like to thank Director, SASE for motivation and keen interest in the study. We are also thankful to Dr. M.R. Bhutiyani, Joint Director, SASE for valuable suggestions and comments. Special thanks to Central Water Commission (CWC) for providing in-situ discharge data for validation.

\section{References}

Ageta Y (2001) Study project on the recent shrinkage of summer accumulation type glaciers in the Himalayas, 1997-1999. Bulletin of Glaciological Research 18: 45-49.

Archer DR, Fowler HJ (2008) Using meteorological data to forecast seasonal runoff on the River Jhelum, Pakistan. Journal of Hydrology 361: 10-23. DOI: 10.1016/j.jhydrol. 2008.07.017

Arora M, Singh P, Goel NK, et al. (2008) Climate variability influences on hydrological responses of a large Himalayan basin. Water Resource Management 22: 1461-1475. DOI: 10.1007/s.11269-007-9237-1
Beniston M (1997) Variation of snow depth and duration in the Swiss Alps over the last 50 years: Links to changes in largescale climatic forcings. Climatic Change 36: 281-300. DOI: 10.1023/A:1005310214361

Beniston M (2003) Climatic change in mountainous regions: a review of possible impacts. Climate Change 59: 5-31. DOI: 10.1023/A:1024458411589

Bhutiyani MR, Kale VS, Pawar NJ (2007) Long-term trends in maximum, minimum and mean annual air temperatures across the northwestern Himalaya during the 2oth Century. 
Climatic Change 85: 159-177. DOI: 10.1007/s10584-0069196-1

Bhutiyani MR, Kale VS, Pawar NJ (2008) Changing streamflow patterns in the rivers of northwestern Himalaya: Implications of global warming in the 20th century. Current Science 95(5): 618-626.

Bhutiyani MR, Kale VS, Pawar NJ (2009) Climate change and the precipitation variations in the north-western Himalaya: 1866-2006. International Journal of Climatology DOI: 10.1002/joc.1920.

Borgaonkar HP, Pant GB, Kumar R (1996) Ring-width variations in Cedras deodara and its climatic response over the western Himalaya. International Journal of Climatology 16: 1409-1422.DOI: 10.1002/(SICI)1097-0088(199612)16:12 <1409::AID-JOC93>3.0.CO;2-H

Butt M, Bilal M (2011) Application of snowmelt runoff model for water resource management. Hydrological Processes 25(24): 3735-3747. DOI: 10.1002/hyp.8099.

Cannone N, Diolaiuti G, Gugliemin M, et al. (2008) Accelerating climate change impacts on alpine glacier forefield ecosystems in the European alps. Ecological Application 18(3): 637-648. DOI: $10.1890 / 07-1188.1$

Crowley TJ (2000) Causes of climate change over the past 1000 years. Science 289: 270-276. DOI: 0.1126/science.289. 5477.270

Day CA (2009) Modelling impacts of climate change on snowmelt runoff generation and streamflow across western US mountain basins: a review of techniques and applications for water resources management. Progress in Physical Geography 33(5): 614-633. DOI: 10.1177/0309133309343131

De US, Mukhopadhyay RK (1998) Severe heat wave over the Indian subcontinent in 1998, in perspective of global climate. Current Science 75(12): 1308-1311.

Diaz HF, Bradley RS (1997) Temperature variations during the last century at high elevation sites. Climatic Change 36: 253279. DOI: 10.1023/A:1005335731187

Diaz HF, Grosjean M, Graumlich L (2003) Climate variability and change in high elevation regions: past, present and future. Climatic Change 59: 1-4. DOI: 10.1023/A:1024416227887

Easterling DR, Horton B, Jones PD, et al. (1997) Maximum and minimum temperature trends for the globe. Science 227: $364-365$.

Fallot JM, Barry RG, Hoogstrate D (1997) Variation of mean cold season temperature, precipitation and Snow depths during the last 100 years in the former depths during the last 100 years in the former Soviet Union (FSU). Hydrological Sciences 42: 301-327.

Hall DK, Riggs GA, Salomonson VV, et al. (2002) MODIS snow cover products. Remote Sensing of Environment 83: 181-194.

Hewitt K (2005) The Karakoram anomaly Glacier expansion and the 'elevation effect,' Karakoram Himalaya. Mountain Resource Development 25(4): 332-340. DOI: 10.1659/o2764741(2005)025[0332:TKAGEA]2.0.CO;2

Huber UM, Bugmann HKM, Reasoner AM (2005) Global Change and Mountain Regions: An Overview of Current Knowledge. Advances in Global Change Research series 23: 650 ISBN 978-1-4020-3508-1.

IPCC, Climate change (2001) The IPCC Third Assessment Report, Vols I (The scientific basis), II (Impacts, adaptation and vulnerability) and III (Mitigation), Cambridge University Press, Cambridge.

IPCC (2007) Climate Change 2007: Climate Change Impacts, Adaptation and Vulnerability, Working Group II Contribution to the Intergovernmental Panel on Climate Change - Fourth Assessment Report Summary for Policymakers.

Jain SK, Goswami A, Saraf A (2009) Snowmelt runoff modelling in a Himalayan basin with the aid of satellite data. International Journal of Remote Sensing 31: 6603-6618. DOI: 10.1080/01431160903433893

Jain SK, Goswami A, Saraf A (2010) Assessment of Snowmelt Runoff Using Remote Sensing and Effect of Climate Change on Runoff. Water Resources Management 24: 1763-1777. DOI: 10.1007/s11269-009-9523-1

Jones PD, Raper SCB, Bradley RS, et al. (1986) Northern hemispheric surface air variation: 1851-1984. Journal of Climate and Applied Meteorology 25: 161-179.

Jones PD, Raper SCB, et al. (1986) Southern hemispheric surface air variation: 1851-1984. Journal of Climate and Applied Meteorology 25: 1213-1230.

Karl TR, Knight RW, Plummer N (1995) Trends in high frequency climate variability in the twentieth century. Nature 377: 217-220. DOI: 10.1038/377217ao

Knappenberger PC, Michaels PJ, Davis RE (2001) Nature of observed temperature changes across the United States during the 20th century. Climate Research 17: 45-53. DOI: 10.3354/cro17045

Larson RP, Byrne JM, Johnson DL, et al. (2011) Modelling climate change impacts on spring runoff for the rocky mountains of Montana and Alberta I: Model development, calibration and historical analysis. Canadian Water Resource Journal 36(1): 17-34.

Li C, Tang M (1986) Changes of air temperature of QinghaiXizang plateau and its neighbourhood in the past 30 years. Plateau Meteorology 5: 322-341.

Lin YP, Hong, NM, Wu PJ et al. (2007) Modeling and assessing landuse and hydrological processes to future land-use and climate change scenarios in watershed land-use planning. Environmental Geology 53: 623-634 DOI: 10.1007/s00254007-0677-y.

Martinec J, Rango A, Roberts R (2008) Snowmelt Runoff Model (SRM) User's Manual (version 1.11). Available online at: http://hydrolab.arsusda.gov/cgi-bin/srmhome/srm4.pdf (accessed in November 2012)

Meng L, Tao L, Li J, et al. (2008) A system for automatic processing of MODIS L1B data. 8th International Symposium on spatial accuracy assessment in Natural Resources and Environmental Sciences, June 2008, Shanghai, China. pp 335-343.

Negi HS, Snehmani, Thakur NK (2008) Operational Snow Cover Monitoring in NW-Himalaya using Terra and Aqua MODIS Imageries. Proceedings International Workshop on Snow, Ice, Glacier and Avalanches, IITMumbai, India, 7-9 January 2008. pp 11-25.

Nichol J, Hang LK, Sing WM (2006) Empirical correction of low sun angle images in steeply sloping terrain: a slope matching technique. International Journal of Remote Sensing 27(3-4): 629-635.DOI: 10.1080/02781070500293414

Mishra VD, Sharma JK, Singh KK, et al. (2009) Assessment of different topographic corrections on AWiFS satellite imagery of Himalaya terrain. Journal of Esrth System and Science 118(1) 11-26.

Oerlemans J (1994) Quantifying global warming from retreat of glaciers. Science 264: 243-245.

Pant GB, Borgaonkar HP (1984) Climate of the hill regions of Uttar Pradesh. Himalayan Research and Development 3(1): $13^{-20 .}$

Pant GB, Borgaonkar HP, Kumar R (1999) Climate variability over the Western Himalaya since little ice age: dendroclimatic implications. In Proceedings of national snow science workshop "Technology in support of snow and avalanche research", Manali (India), October 1999.

Qiang F, Celeste MJ, Stephen GW, et al. (2004) Contribution of stratospheric cooling to satellite inferred tropospheric temperature trends. Nature 429: 55-57. DOI: $10.1038 /$ nature 02524

Riggs H, Hall DK (2002) Reduction of cloud obscuration in the MODIS snow data product. In Proceedings of 59th Eastern Snow conference, Stowe, Vermont USA, June 2002.

Rebetez M (2004) Summer 2003 maximum and minimum daily temperature over a $3300 \mathrm{~m}$ altitudinal range in the Alps. Climate Research 27: 45-50. 
Schaer C, Vidale PL, Luthi D, et al. (2004) The role of increasing temperature variability in European summer heat waves. Nature 427: 332-336. DOI: $10.1038 /$ natureo2300

Seko K, Takahashi S (1991) Characteristics of winter precipitation and its effects on glaciers in Nepal Himalaya. Bulletin of Glacier Research 9: 9-16.

Sharma SS, Ganju A (2000) Complexities of avalanche forecasting in western Himalaya - an overview. Cold Region Science and Technology 31: 95-102.

Sharma V, Mishra VD, Joshi PK (2012) Snow cover variation and streamflow simulation in a snow-fed river basin of the Northwest Himalaya. Journal of Mountain Science 9: 853868 DOI: 10.1007/s11629-012-2419-1.

Shekhar MS, Chand H, Kumar S, et al. (2010) Climate-change studies in the western Himalaya. Annals of Glaciology 51(54): 105-112. DOI: $10.3189 / 172756410791386508$

Singh P, Bengtsson L, Berndtsson R (2003) Relating air temperatures to the depletion of snow covered area in a Himalayan Basin. Nordic Hydrology 34(4): 276-283. DOI: $10.2166 /$ nh.2003.016

Singh P, Bengtsson L (2004) Hydrological sensitivity of a large Himalayan basin to climate change. Hydrological Processes 18 2363-2385, DOI: 10.1002/hyp.1468.

Thompson LG, Yao T, Mosley-Thompson E, et al. (2000) A high-resolution millennial record of the South Asian monsoon from Himalayan ice cores. Science 289: 1916-1919. DOI: 10.1126/science.289.5486.1916

Villaba R, Lara A, Boninsegna JA, et al. (2003) Large scale temporal changes across the southern Andes: 20th century variations in the context of the past 400 years. Climatic Change 59: 177-232.

Vinnikov K, Graisman P. Ya, Lugina KM (1990) Empirical data on contemporary global climatic changes (Temperature and Precipitation). Journal of Climate 3: 662-677. DOI: 10.1175/ 1520-0442(1990)003<0662:EDOCGC>2.0.CO;2

Vuille M, Bradley RS, Werner M, et al. (2003) 2oth Century climate change in the tropical Andes: observations and model results. Climatic Change 59: 75-99. DOI: 10.1007/978-94015-1252-7_5

Wang J, Li HY, Hao XH (2010) Reponses of snowmelt runoff to climatic change in an inland river basin, Northwestern China, over the past 50a. Hydrological Earth System and Sciences Discussions 7: 493-528.

Wibig J, Glowicki B (2002) Trends in minimum and maximum temperature in Poland. Climate Research 20: 123-133.

Zhai P, Sun A, Ren F, et al. (1999) Changes in climate extreme in China. Climate Change 42: 203-218. DOI: 10.1007/978-94015-9265-9_13 